\title{
Phenotypic Characterization of Indigenous Goats in North Shewa Zone, Amhara Region, Ethiopia
}

\author{
Hailu Tilahun", Aynalem Haile, Ahmed Seid \\ Salale University College of Agriculture and Natural Resource P.O.Box: 245, Fiche, Ethiopia \\ International Center for Agricultural Research in the Dry Areas (ICARDA) P.O. Box: 5689, Addis Ababa, \\ Ethiopia \\ Jimma University College of Agriculture and Veterinary Medicine P.O.BOX: 307, Jimma, Ethiopia
}

*Corresponding Author: Hailu Tilahun, Salale University College of Agriculture and Natural Resource P.O.Box: 245, Fiche, Ethiopia

\begin{abstract}
The study was conducted with the objectives of phenotypically characterize the goat population. Data for qualitative and quantitative characters were collected from a total of 630 goats $(210$ goats from each district). Observations on qualitative traits were analyzed for male and female goats separately using frequency procedure of SPSS. Whereas, quantitative traits were analyzed using the Generalized Linear Model procedures of the statistical analysis system (SAS, 2014). Majority of goat coat color was red color in Berehet and Basona-worena district while in Minjar-shenkora white is dominant and white with other coat colors were observed. Sex and district of goats had significant effect on all body measurements. Age classes of goats had significant $(p<0.05)$ effect on body weight and most of the linear body measurements. For all the measurements compared, Minjar-shenkora district had higher values than other districts. The result of the multiple regression analysis showed that chest girth explained more variation than any other linear body measurements in both does (91\%) and bucks (92\%). The prediction of body weight could be based on regression equation $y=-53.23+1.18 x$ for female sample goat population and $y=-45.16+1.06 x$ for male sample goat population where $y$ and $x$ are body weight and chest girth, respectively.
\end{abstract}

Keywords: Phenotypic characterization, regretion, body weight, correlation.

\section{INTRODUCTION}

Ethiopia has the largest livestock population in Africa and is a homeland of large number of goat populations which are kept in various production systems and different agro-ecological zones of highlands, sub-humid, semi-arid and arid environments (Getnet,2016). Livestock plays an important role in providing export commodities, such as live animals, hides and skins to earn foreign exchanges for the country (CSA, 2013). Goat production is one of the integral parts of livestock farming an activity of the country. The majority of the goat population is found in large flocks in the arid and semi-arid Lowlands. Goats in the highlands are widely distributed in the mixed crop-livestock production systems with very small flock size (Tesfaye, 2004). Almost all goat population is managed by resource poor smallholder farmers and pastoralists under traditional and extensive production systems (Solomon, 2014).

According to CSA (2016-17), the number of goats reported in the country is estimated about 30.20 million and with respect to breed, almost all of the goats are indigenous which accounts for $99.99 \%$ (CSA, 2013). The previous research (FARM Africa, 1996) on phenotypic characterization indicated that there are about 12 goat types in Ethiopia while, a genetic study that used microsatellite markers showed only eight distinctively different types of goats in Ethiopia (Tesfaye, 2004). However, the current molecular study on the domestic goats by Getnet (2016) does not support the former classifications of the indigenous goat populations. After detailed analysis of the goat population based on production systems, agro-ecologies, goat families, admixture and phylogenetic network analyses he classified the 12 Ethiopian goat populations in to six goat types.

Goats are browsers and highly selective feeders and have strategy that enables them to thrive and produce even when feed resources, except bushes and shrubs, appear to be non-existent. Thus, the 
presence of goats in mixed species grazing systems can lead to a more efficient use of the natural resource base and add flexibility to the management of livestock. This characteristic is especially advantageous in fragile environments (Adane and Girma, 2008). According to Workneh (1992), the habitats of these indigenous goat breeds extend from the arid lowlands (the pastoral and agro-pastoral production system) to the humid highlands (mixed farming systems) covering even the extreme tsetseinfested areas of the country. Furthermore, goats have small body size, broad feeding habits, adaptation to unfavorable environmental conditions and short reproductive cycle. These provide them comparative advantage over other species to suit the circumstances of especially resource poor livestock keepers (Alemayehu, 1993; Silanikove, 2000; Misra and Singh, 2002). They play an important socioeconomic role such as food source, milk, skin, manure, income generation, as a prestige, as a wealth status and socio-cultural wealth in rural areas (Tesfaye, 2009; Bekalu; 2014; Alubel, 2015 and Alefe, 2015). In addition to these, there are no banking facilities in rural areas and an easy way to store cash for future needs are through the purchase of small ruminants (IBC, 2004).

Despite the wide distribution and large size of Ethiopian goat population, the productivity and the contribution of this sector to the national economy is below the potential. Goat production accounts for $16.8 \%$ of the total meat supply (Ameha, 2008) and $16.7 \%$ of milk consumed in the country (Tsedeke, 2007). The average annual meat consumption per capita in the country is estimated to be 8 $\mathrm{kg} /$ year which was lower than the global average meat consumption $(38 \mathrm{~kg} /$ year $)$ and the average meat consumption of USA (124 kg per capita per year) (Ameha, 2008). The average carcass weight of Ethiopian goats is $10 \mathrm{~kg}$, which is the second lowest in sub-Saharan Africa (Adane and Girma, 2008). This may be due to different factors such as poor nutrition, prevalence of diseases, lack of appropriate breeding strategies and poor understanding of the production system as a whole (Tesfaye, 2009). Thus, it is urgent to improve the low productivity to satisfy the increasing demand for animal protein, improve the livelihood of livestock keepers and economic development of the country at large.

Genetic improvement is one way to increase the productivity of the goat resource in the country. However, identification, characterization and documentation of the breeds or strains and the type of environment in which they are kept, description of the breed characteristics, their adaptation as well as production potentials in those environments are the prerequisite for genetic improvement work (Workneh, 1992). Moreover, for designing sustainable genetic improvement program, considering the compatibility of the genotypes with the farmers' breeding objectives and the production systems are crucial (Markos, 2006). To design improvement measures relevant to specific systems and thereby properly respond to the growing domestic and foreign demands for live goats and goat products; characterizing different goat breeds/populations, describing their external production characteristics in a given environment, management and identifying different constraints are important.

Even though various research and development activities have been carried out in the past, no significant increase in productivity was achieved in the country (FARM Africa, 1996, Alemayehu, 1993; Nigatu, 1994; Mahilet, 2012; Belete, (2013); Alefe, 2014; Ahmed, 2013; Alubel, 2015; Tsigabu, 2015; Feki, 2013). Recently in Amhara region Halima (2012), Hulumin (2014) and Alubel (2015) characterized the phenotypic characteristics, goat production systems, and production and reproduction performances. However North Shewa zone is less focused area especially on goat genetic resource rather than two decade of FARM Africa (1996) work.

From Amhara region, North Shewa zone has the second largest goat population around 820,947 heads (CSA, 2015-16) this may be the significance of goats rather than other livestock species. Despite its large size and significance in terms of meat, cash income and skin production, there is lack of information on these goat genetic resources. Moreover, updating of the only previous FARM Africa (1996) phenotypic characterization work in the study area is vital since genetic resources and production systems are not static if there anchange in phenotypic and Morphometric parameters. In addition absence of adequate information on the characteristics of breeds potentially leads to wrong decision and genetic erosion through cross breeding, replacement and dilution (Zewdu, 2008). Thus characterizing this goat genetic resource is essential for efficient utilization and conservation of genetic resources as well as to plan different developmental strategies like community-based genetic improvement program.

\subsection{Objectives}

\subsubsection{General Objective}

- To characterize indigenous goat populations in North Shewa zone 


\subsubsection{Specific Objectives}

- To phenotypically characterize indigenous goats in the study area

\section{MATERIALS AND METHODS}

\subsection{Description of the Study Area}

This study was conducted in three districts namely, Berehet, Minjar-shenkora and Basona -Worena of North Shewa zone Amhara regional state. Berehet is one of the districts in the North Shewa zone of Amhara regional state and it is geographically located at latitude of $9^{0} 11^{\prime} 43.72^{\prime \prime} \mathrm{N}$ and at longitude of $39^{\circ} 44^{\prime} 14.12^{\prime \prime} \mathrm{E}$ and it has altitude ranges from 937 - 3,190 m.a.s.l. The mean annual rainfall of the area varied from $700-950 \mathrm{~mm}$ and the mean annual temperature varies from $18^{\circ} \mathrm{c}$ to $30^{\circ} \mathrm{c}$. This district had three climate zones i.e. highland $3 \%$, midland $17 \%$ and lowland $80 \%$. The center of the district, Metehbila town, is located at a distance of $388 \mathrm{~km}$ away from the zonal city, Debrebrehane, and at $210 \mathrm{~km}$ away from Addis Ababa on the main road running from Modjo to the district. There are 9 rural and 1 urban kebeles in the woreda and has a total area of 77,205.26 hectares North Shewa zone Office of agriculture and Rural Development (2013).

The livestock population in Berehet is about 20,419 thousand sheep, 40,231 thousand goats, 30, 860 thousand cattle, 2,760 thousand camels, poultry 52,377 thousand and 8, 334 thousands equine. The overall major farming activities were mixed crop and livestock farming, the area is suitable for both rearing of livestock and cultivating crops with a favorable climate for agriculture but productivity of crop and livestock is decreased due to recurrent drought occurrence (Berehet district office of livestock and fishery resource, 2017). In the district crops also grown like teff, sorghum, masho, chickpea and wheat are the main crops grown in the main rainy season. Minjar-shenkora District is one of the districts' in the North Shewa zone of Amhara regional state and it is geographically located at a latitude of $8^{0} 55^{\prime} 23.67^{\prime \prime} \mathrm{N}$ and at longitude of $39^{\circ} 25^{\prime} 36.49^{\prime \prime} \mathrm{E}$ and it has altitude ranges from 1,040 - 2,380 m.a.s.l. The mean annual rainfall of the area varied from $700-950 \mathrm{~mm}$. The rainfall pattern is bimodal and the main rainy season falls from July to September. The mean annual temperature varies from $10.6^{\circ} \mathrm{c}$ to $27.4^{\circ} \mathrm{c}$. Climatologically there are three zones i.e. highland $4.3 \%$, midland $70.9 \%$ and lowland $24.8 \%$ (North Shewa zone Office of Agriculture and Rural Development, 2013).

The center of the district, Arreti town, is located at a distance of $263 \mathrm{~km}$ away from the zonal city, Debrebrehane, and at $135 \mathrm{~km}$ away from Addis Ababa. The livelihood of most population in the district is dependent on agriculture. The district has a good potential both in crop production and livestock production. Livestock has also a major role in the farming system of the district. The major livestock population in the district is about 95,270 thousand cattle, 74, 069 thousand goat, 57, 603 thousand sheep, 26, 349 thousand equine, 8, 131 thousand camel and 168, 702 thousand poultry. Crops like teff, chickpea, sorghum, wheat and lentil are major crops grown in the district (Minjarshenkora district office of livestock and fishery resource, 2017).

Basona-Worena ("Baso and Worena") is one of the districts' in the Amhara Region of Ethiopia. Located at the eastern edge of the Ethiopian highlands in the Semien Shewa zone and it is geographically located at a latitude of $9^{0} 35^{\prime} 36.09^{\prime \prime} \mathrm{N}$ and at longitude of $39^{\circ} 18^{\prime} 23.12^{\prime \prime} \mathrm{E}$ its altitude is ranges from $1300-3,400$ m.a.s.l. The mean annual rainfall of the area varied from $950-1200 \mathrm{~mm}$. The mean annual temperature varies from $10^{\circ} \mathrm{c}$ to $22^{\circ} \mathrm{c}$ Climatologically there are four zones i.e. wurchi $2 \%$, highland 50\%, midland $46 \%$ and lowland 2\% (North Shewa zone Office of agriculture and Rural Development, 2013).

The center of the district, office of administration, is located at zonal city Debrebrehane, a distance of $130 \mathrm{~km}$ away from Addis Ababa, but it has one special kebeles administration Qeyit town it is located at a distance of $10 \mathrm{~km}$ away from Debrebrehane. The livelihood of most population in the district is dependent on agriculture. Livestock has also a major role in the farming system of this district. The total number of livestock population in this district is about 110, 945 thousand cattle, 48,414 thousand goats, 151,965 thousand sheep, 11,417 thousand equine, 380,989 thousand poultry and 6,146 beehives 
were major livestock species reared in the district (Basona-worena district office of livestock and fishery resource, 2017). Bean, pea, barley, lentil, vetches and wheat were the major crops grown in this area.

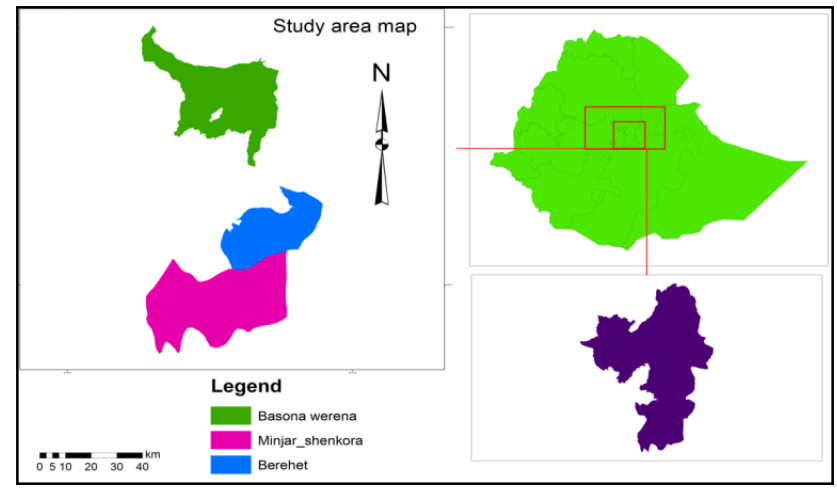

Figure1. Map of Ethiopia, North Shewa, Basona-worena, Berehet and Minjar-Shenkora district.

\subsection{Sampling Techniques and Sample Size Determination}

\subsubsection{Sampling Techniques}

Based on the information obtained from secondary data sources the districts (twenty-seven) in the zone were stratified according to their agro-ecological variations low land $/$ kola $(<1500$ m.a.s.l), mid land/woyna-dega (1500-2500 m.a.s.l), and high land/dega (>2500 m.a.s.l). From each agro ecological zones, one sample district was purposively selected based on relatively large goat population and agro-ecology representations. From each district, three kebeles were purposively selected again based on relatively large goat population and agro-ecology representations. For selecting sample goats from the three kebeles of each district, castrated goats, pregnant doe, kids, buck kids and doe kids were avoided from the goat population to enhance accuracy for body weight and linear body measurements (LBMs) and to represent the adult goat population. Then, sample goats were taken by using simple random sampling method. Dentition was used to determine the estimated age class of goats and goats which had one and above pair of permanent incisor (1PPI) was used for body measurements and qualitative trait descriptions.

\subsubsection{Sample Size Determination for Household and Goats}

The sample size of goats was also determined by the formula given by Cochran's (1977) as FAO (2012) recommended for phenotypic characterization of livestock for simple random sampling.

$$
n=\frac{Z^{2} *(p)(q)}{e^{2}}
$$

$\mathrm{n}=$ sample size

$\mathrm{Z}=$ standard normal deviation (1.96 for $95 \%$ confidence level)

$\mathrm{P}=0.15$ (estimated population variability proportion, $15 \%$ )

$\mathrm{q}=1$-P i.e. $(0.85)$

$\mathrm{e}=$ level of precision $(0.05)$

Based on the formula

This is for one agro ecology, for the three agro ecology $3 * 196=588$. In order to increase the accuracy adding up to $10 \%$ of the sample size on this calculated sample is recommended and $7 \%$ of the sample size was added in this calculated sample. $588 * 7 / 100=41.16,588+41.16=629.16=630$ goats used for collecting data from qualitative and quantitative traits. Based on FAO (2012), from the total sample size $90 \%$ of goats were female and the remaining $10 \%$ of goats was male.

\subsubsection{Data Types and Collection Methods for Phenotypic Characterization}

Data (for quantitative and qualitative traits) was recorded based on breed morphological characteristics descriptor list of FAO (2012) for phenotypic characterization of goat. Data for, heart girth (HG), body length (BL), wither height (WH), rump height (RH), chest depth (CD), shoulder 
width (SW), pelvic width (PW), ear length (EL), rump length (RL), rump width (RW), horn length (HL), cannon bone length (CBL), cannon bone circumference (CBC) and head length (HL) was collected using tailors measuring tape while body weight (BW) was measured using suspended spring balance (Appendix III). Data was generated for qualitative traits like coat color pattern, coat color type, horn shape, horn orientation, ear orientation, hair type, hair length, head profile, back profile, rump profile, wattle presence, ruff presence and bear presence were collected through visual observations (Appendix III).

\subsection{Data Management and Statistical Analysis}

All data gathered during the study period was coded and recorded in Microsoft Excel 2007. Preliminary data analysis like homogeneity test, normality test was employed before conducting the main data analysis for quantitative data. Different types of statistical analysis were used depending upon the nature of the data. All data was analyzed using SAS version 9.3 (2014).

\subsubsection{Data Analysis for Qualitative and Quantitative Traits}

Observations on qualitative traits were analyzed separately for male and female goats using descriptive statistics using statistical package for social sciences (SPSS 20.). Chi-square $\left(\mathrm{x}^{2}\right)$ test was also applied to test $(\mathrm{p}<0.05)$ the statistical significance of categorical variables. A general linear model procedure (PROC GLM) of SAS was used for quantitative variables. District, sex, age group and sex by age interaction were fitted as fixed effect while quantitative traits except scrotum circumference for females were fitted as response variables. Least square means (LSM) with their corresponding standard errors was calculated for each trait over sex, age, location and age by sex interaction. When analysis of variance declared significant difference, least square means was compared by using Tukey-Kramer test.

The model employed for analyses of the least square mean in female and male goats except scrotal circumference was: $Y i j k l=\mu+A_{i}+S_{j}+D_{k}+(A S)_{i j}+e_{i j k}$

Where:

Yijk $=$ the observation of body weight and LBMs excluding scrotum circumference in the $\mathrm{i}^{\text {th }}$ age group $\mathrm{j}^{\text {th }}$ sex and $\mathrm{k}^{\text {th }}$ district

$\mu=$ overall mean

$\mathrm{A}_{\mathrm{i}}=$ the effect of $i^{\text {th }}$ age group ( $\mathrm{i}=1 \mathrm{PPI}, 2 \mathrm{PPI}, 3 \mathrm{PPI}$ and 4PPI)

$S_{j}=$ the effect of $j^{\text {th }}$ sex $(j=$ male, female)

$\mathrm{D}_{\mathrm{k}}=$ the effect of $\mathrm{k}^{\text {th }}$ district $[\mathrm{K}=$ highland (Basona-worena), midland (Minjar-shenkora), low land (Berehet)]

$(\mathrm{AS})_{\mathrm{ij}}=$ the interaction effect of $\mathrm{i}^{\text {th }}$ age group and $\mathrm{j}^{\text {th }}$ sex

$\mathrm{e}_{\mathrm{ijkl}}=$ random residual error

Model used for the least square mean analysis in males for scrotal circumference was:

$Y i j=\mu+D i+A j+e i j$

Where: $\mathrm{Yij}=$ Scrotal Circumference

$\mu=$ Overall mean

$\mathrm{Di}=$ the fixed effect of $\mathrm{i}^{\text {th }}$ district $(\mathrm{i}=$ Berehet, Basona-worena and Minjar-shenkora)

$\mathrm{Aj}=$ the fixed effect of $\mathrm{j}^{\text {th }}$ age classes $(j=1 P P I, 2 P P I)$

eij= random residual error

Correlations (Pearson's correlation coefficients) between body weight and other linear body measurements were computed within each sex. To estimate body weight from linear body measurements, all body measurements for males and except scrotum circumference (SC) for females was together entered into the model below, and then body weight was regressed on those body measurements for all age groups of males and females using maximum adjusted $\mathrm{R}^{2}$ method (SAS, 9.3) to determine the best fitted regression equation for the prediction of body weight from LBMs. Best 
fitted model was selected based on coefficient of determination (adjusted $\mathrm{R}^{2}$ ), Alkaike's information criteria (AIC), the mallow's parameters C (P), Schwarz Bayesian criteria (SBC) and mean square error (MSE). In step one, all the above independent variables were together entered into the model for males and excluding SC for females, and a group of variables having maximum adjusted $\mathrm{R}^{2}$ and minimum MSE was selected for each sex. Then, in step two, the variables which were selected based on maximum adjusted $\mathrm{R}^{2}$ and minimum MSE was entered together into the model to find the best fitted regression equation. The following model was used for the estimation of body weight from LBMs.

For male:

$\mathrm{Y}=\beta 0+\beta 1 \mathrm{X} 1+\beta 2 \mathrm{X} 2+\beta 3 \mathrm{X} 3+\beta 4 \mathrm{X} 4+\beta 5 \mathrm{X} 5+$ ej Where:

$\mathrm{Y}=$ the dependent variable; body weight

$\beta_{0}=$ the intercept

$\mathrm{X} 1, \mathrm{X} 2, \mathrm{X} 3, \mathrm{X} 4, \mathrm{X} 5$ were the independent variables (HG, BL, HoL, CBL, HeL) respectively.

$\beta 1, \beta 2, \beta 3, \beta 4$ and $\beta 5$ were regression coefficients of the variables $X 1, X 2, X 3, X 4$ and $X 5$

$\mathrm{ej}=$ the residual random error

For female:

$\mathrm{Y}=\beta 0+\beta 1 \mathrm{X} 1+\beta 2 \mathrm{X} 2+\beta 3 \mathrm{X} 3+\beta 4 \mathrm{X} 4+\beta 5 \mathrm{X} 5+\beta 6 \mathrm{X} 6+\beta 7 \mathrm{X} 7+$ ej Where:

$\mathrm{Y}=$ the dependent variable; body weight

$\beta_{0}=$ the intercept, $\mathrm{X} 1, \mathrm{X} 2, \mathrm{X} 3, \mathrm{X} 4, \mathrm{X} 5, \mathrm{X} 6$, and X7 were the independent variables (HG, RH, PW, $\mathrm{SW}, \mathrm{RL}, \mathrm{CBC}$ and $\mathrm{CBL}$ ) respectively.

$\beta 1, \beta 2, \beta 3, \beta 4, \beta 5, \beta 6$ and $\beta 7$ were regression coefficients of the variables $\mathrm{X} 1, \mathrm{X} 2, \mathrm{X} 3, \mathrm{X} 4, \mathrm{X} 5, \mathrm{X} 6$ and $\mathrm{X} 7$

ej $=$ the residual random error

\section{RESULT AND DISCUSSION}

\subsection{Phenotypic Characterization of Goat Population}

\subsubsection{Qualitative Traits of the Sampled Goat Population}

The qualitative trait of indigenous goats found in Berehet, Basona-worena and Minjar-shenkora districts are presented in Table 24. The chi-square test indicated that there was significant difference $(\mathrm{P}<0.05)$ between goat population in the three districts (Berehet, Basona-worena and Minjarshenkora districts) for coat color pattern, coat color type, hair length, horn shape, horn orientation and head profile. However, there was no significant difference $(\mathrm{P}>0.05)$ between goat population in the three districts (Berehet, Basona-worena and Minjar-shenkora districts) for wattle presence, rump profile, back profile, ruff presence, beard presence and ear orientation.

The most frequent coat color pattern observed in the study area was plain $(61.0 \%$ in Berehet, $69.0 \%$ in Basona-worena and 76.7\% in Minjar-shenkora). Similarly, Ahmed (2013) reported that majority (75.49\%) of goat population in Horro Guduru Wollega zone had plain coat color pattern. In contrast to this result, Bekalu (2014) reported that nearly half of (44.5\%) goat population in West Gojam zone had patch coat color pattern. The most frequently observed coat color type in Berehet and Basonaworena districts was red $(31.0 \%$ in each district) whereas $21.4 \%$ of goat population in Minjarshenkora district had white coat colour.

In the study area particularly in Minjar-shenkora district, white is dominant coat colour type and in the sample populations white with different colors (red, black, fawn), uniform red, fawn, black, brown, gray and roan coat color types were also observed with small and varied frequencies. This indicated that goat populations found in the study area had a wide range of coat colour types. In contrary, FARM Africa (1996) reported that the dominant coat colour type of Central Highland goat was reddish-brown. The reason could be FARM Africa (1996) covered very wide areas (central Tigray, Wollo, Gondar and Shewa) for the description of Central Highland goats and there may be heterogeneity. Black coat color was less frequent than white and red ones. This indicates that farmers' have specific coat color preference.

The majority of goat population in Berehet (79.5\%), in Basona-worena, (67.6\%) and in Minjarshenkora (69.5) had smooth hair coat type and small proportion of them had long straight hair (12.7), 
curly rough $(6.3 \%)$, glossy $(4.0 \%)$ and dull $(4.8 \%)$ haired coat types. With respect to hair length the majority of goats in the study area had medium sized (86.3\%) and the remaining (13.7\%) of them had long hair across the study area.

In the study area, $100.0 \%$ of goat population in Basona-worena, $99.5 \%$ in Minjar-shenkora district had horn whereas, in Berehet district few (6.2\%) of the goat population were polled. The absence of polled goats in the study areas, particularly in Basona-worena and Minjar-shenkora districts were in line with the previous studies by FARM Africa (1996) and Alubel (2015) who reported that the majority $(90.38 \%)$ of Abergelle and Central Highland goats were horned. The proportions of polled bucks were lower than does in the population of Berehet district; this may be the higher frequency of short-horned allele (HoP) for males. In horned goats different horn shapes (curved, spiral and straight) and orientations (backward, upward and polled) were observed in the study area. The most observed horn shapes in the goat population were curved (67.5\%), spiral (16.5\%) and straight (16.0\%) and the majority $(85.6 \%)$ of goat population had back ward horn orientation. In contrast to this result, Hulumin (2014) reported that the dominant horn shape in Bati indigenous goats was straight $(96.7 \%)$. The current result is in line with the previous studies reported by FARM Africa (1996) and Alubel (2015) who reported that the majority of goats $(74.32 \%)$ had curved and $(87.33 \%)$ backward horn shape and orientation in Central Highland and Abergelle goats, respectively.

The observed ear orientation in the study areas were carried horizontally $(67.3 \%)$, erect or forward (14.3), pendulous $(5.9 \%)$ and semi-pendulous $(12.1 \%)$ were observed in the population. Similarly, Alubel (2015) reported that almost all (98.16\%) of Abergelle goats had horizontal ear orientation. Most $(82.7 \%)$ of the goat population in the study area had straight head profiles. However, the proportion of concave head profile (42.9\%) in Berehet was mach higher than the other district $(5.2 \%$ in Basona-worena and 3.8\% in Minjar-shenkora districts). The presence of beard and ruff was influenced by sex and male goats had higher beard and ruff than females. The predominant back profiles were straight (80.5\%), slopes up towards the rump (18.7\%) and curved or dipped (0.8\%) back profile. The most frequent rump profiles were roofy $(66.8 \%)$ the remaining percentage was sloping $(25.2 \%)$ and flat $(7.9 \%)$. The presence of wattle in the study area was less pronounced for both male and female populations. Totally, only $6.8 \%$ of both male and female goat population possessed wattle in the study area.

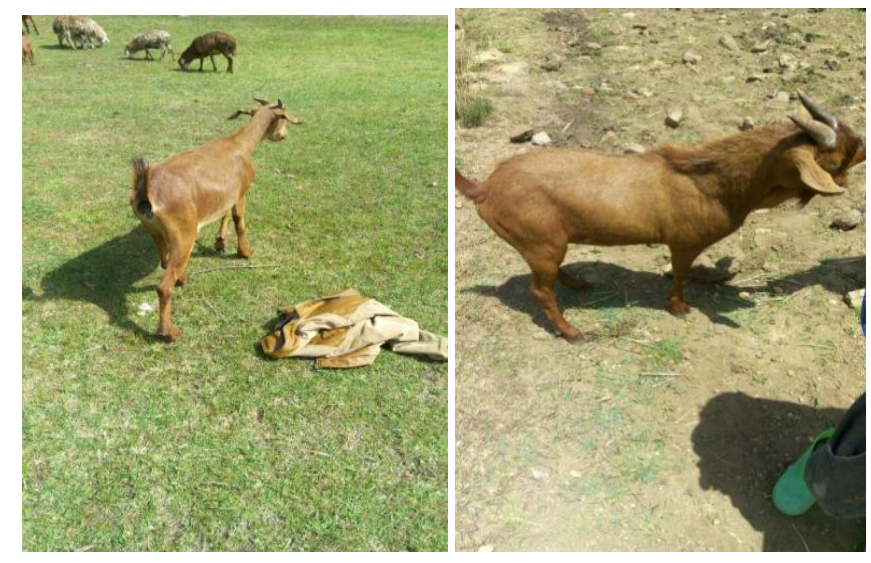

Figure2. Female and male goats in Basona- worena district.

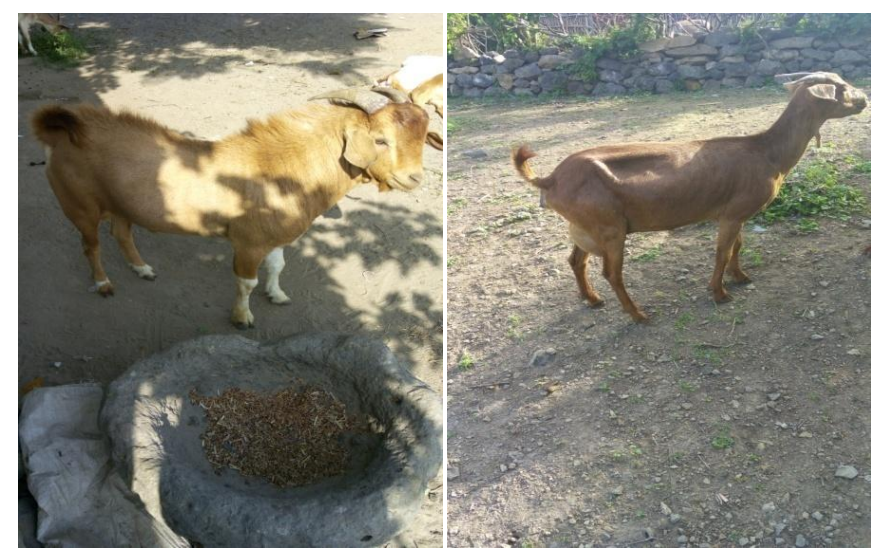

Figure3. Male and female goat's photo that found mostly in Berehet district 


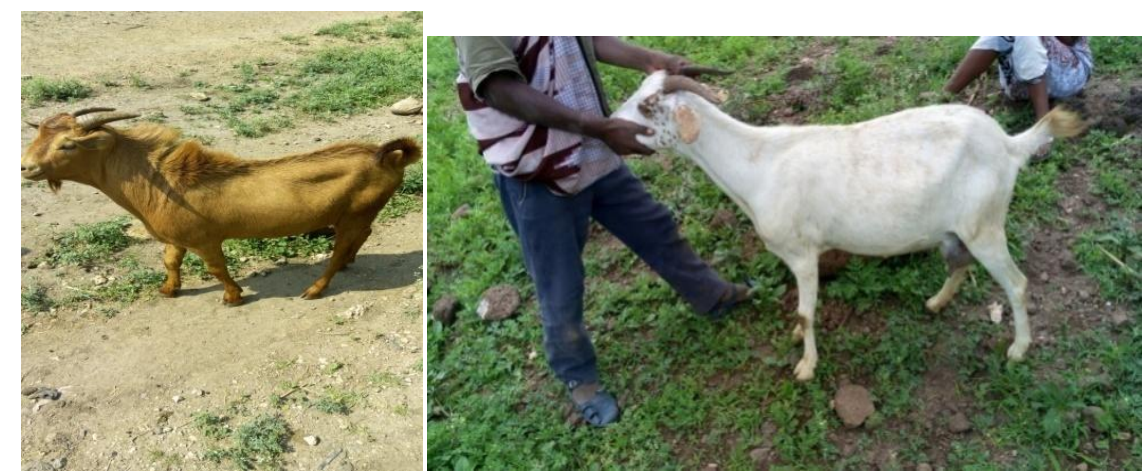

Figure4. Male and female goats in Minjar-shenkora district

\subsubsection{Body Weight and Linear Body Measurements}

The body weight and linear body measurements of indigenous goat in the study area is presented in Table 25 . And the least square analysis of variance for quantitative traits was presented in appendix IV.

Sex effect: - In the study area, it was very difficult to found males in the age class of 3PPI and greater than 4PPI. Due to this reason, the sex effect was only done for males up to 2 PPI and for females up to 2PPI age groups to avoid the effect of 3PPI and 4 PPI females on 1PPI and 2PPI males for only quantitative traits. The least square means for the effect of sex had significant $(<0.05)$ effect on body weight and all body measurements. Male goats were consistently higher values than the corresponding values in females for all significantly affected traits. This might be due to hormonal effect, that is, release of androgen (which is known to have growth and weight - stimulating effects) in male animals after the testes are well developed (Frandson and Elmer, 1981).

Age effect: - The size and shape of the animal increases until the animal reach its maturity and the effect of age on body weight and other body measurements were also observed in different goat breeds of Ethiopia Yoseph (2007). Body weight and all body measurements were significantly affected $(\mathrm{p}<0.05)$ by age. Body weight and all body measurements were increased as the age increased from the youngest (1PPI) to the older (4PPI) age group. This is in agreement with the finding of Tsigabu (2015) in Nuer zone indigenous goats and Yaekob et al. (2015) on Woyto-Guji goats.

District effect: -The effect of district is also significant $(\mathrm{P}<0.05)$ for all quantitative measurements, in the three districts. For all body measurements of goats, in Basona-worena district had significantly lower value $(\mathrm{P}<0.05)$ than goats in Berehet and Minjar-shenkora districts. This may be the effect of agro-ecology and the management difference between the districts. Moreover the farming system is dependent on extensive grazing without supplementation, the size and productivity of the grazing land can be taken as the sole component of the environmental factors affecting livestock productivity Yaecob et al. (2015). Generally lower values were observed in all of the linear measurements for (highland Agro ecologies) Basona-worena district compared to (low land) Berehet district this might be due to management practice and grazing land difference this is in line with Belay et al.(2017) who reported the lowland goats had a higher measurement value than the highland goats. In contrast to this result Yaekob et al. (2015) reported that on Woyto- Guji goats the highland have higher value than the low land. The significant variation between districts in this study could be the zone has three different agro ecologies which allowed the existence both highland and lowland goat breeds in the zone.

Sex by age interaction: - the sex and age interaction effect was also only done for males up to 2 PPI and for females up to 2PPI age groups to avoid the effect of 3PPI and 4 PPI females on 1PPI and 2PPI males for only quantitative traits. The interactions between sex and age groups were also significant $(\mathrm{P}<0.05)$ on body weight and all body measurements except EL. In each age group all the parameters considered, males showed significantly $(\mathrm{P}<0.05)$ higher measurements than females except EL. This condition was expected because of there is hormonal difference between males and females. The value of body measurements for goats of both sexes increased as dentition class increased from 1PPI to 2PPI for both male and female goats.

The present finding reflected that there were wide variations among the three districts which influenced all the quantitative traits studied. Traits with low overall $\mathrm{R}^{2}$ with the corresponding 
high coefficient of variation (CV) values such as body weight in the present study reflected that the heterogeneity was within the population while the reverse (high overall $\mathrm{R}^{2}$ and low $\mathrm{CV}$ values such as heart girth) indicated heterogeneity between populations. Therefore, the varying coefficients of variation in this study attributed to both population and individual differences.

The average body weight in the current study was $35.65 \pm 0.39 \mathrm{~kg}$ for $4 \mathrm{PPI}$ for female goat population which is comparable with the reported of (Ahmed, 2013) 36.4 $\pm 0.8 \mathrm{~kg}$ in Horro Guduru Wollega zone. On the other hand this value was higher than $29.13 \pm 0.22 \mathrm{~kg}$ (Solomon, 2014) and $33.11 \pm 0.20 \mathrm{~kg}$ yaekob et al. (2015) for western lowland and Abergelle goat and Woyto Guji goats. which might be resulted due to breed and geographical differences. In the current study the average body weight of female goat $26.43 \pm 0.22 \mathrm{~kg}$ was lower than the previous FARM Africa (1996) report $30.1 \pm 5.4 \mathrm{~kg}$ on this breed. This deviation could be indication of the decrease of performance through time because of the change in environment and production systems such as drought and decreasing of grazing land. On the other hand uncontrolled mating leads to inbreeding, indiscriminate breeding practices, random selection of goats decrease the performance of goats. The linear body measurement result showed that the studied population was generally better than Woyto Guji goat population and western lowland goat.

\subsubsection{Correlation between Body Weight and Linear Body Measurements}

The phenotypic correlation coefficients ( $r$ ) obtained between the live body weight and linear body measurements of sampled goats is presented in Table 27. The coefficients of correlation between body weight and measured quantitative traits were varied from very highly significant $(p<0.0001)$ to non-significant $(p>0.05)$. Most of the quantitative body measurement traits had significant $(\mathrm{P}<0.05)$ correlation with body weight of both male and female goats in this study except ear length in male. In females heart girth $(\mathrm{r}=0.91)$, body length $(\mathrm{r}=0.89)$, height at wither $(\mathrm{r}=0.87)$, rump height $(\mathrm{r}=0.86)$, chest depth $(\mathrm{r}=0.79)$ and shoulder width $(\mathrm{r}=0.87)$ showed strong positive correlation with body weight. Cannon bone circumference (0.69), pelvic width $(\mathrm{r}=0.74)$, cannon bone length $(r=0.74)$, head length $(r=0.50)$, rump length $(r=0.68)$, rump width $(r=0.58)$ and horn length $(\mathrm{r}=0.53)$ had moderate positive correlation with body weight. The high correlation of different measurements with body weight would imply these measurements can be used as indirect selection criteria to improve live weight (Khan et al., 2006; Solomon, 2008) or could be used to predict body weight.

In males positive and strong relationship were also found between body weight and chest girth $(\mathrm{r}=0.92)$, body length $(\mathrm{r}=0.91)$, wither height $(\mathrm{r}=0.88)$, rump height $(\mathrm{r}=0.89)$, chest depth $(\mathrm{r}=0.65)$, shoulder width $(\mathrm{r}=0.84)$, pelvic width $(\mathrm{r}=0.75)$, horn length $(\mathrm{r}=0.68)$ and scrotal circumference $(\mathrm{r}=0.77)$. From these quantitative measurements, the most strong relationship was found between heart girth and body weight for both sexes ( $r=0.92$ for males; $r=0.91$ for females). This indicated that either heart girth only or by combining with other quantitative traits could suggest a good estimator for predicting live body weight for the goats. Similarly, Bekalu (2014), Alubel (2015), Alefe (2015) and Tsigabu (2015) on indigenous goats reported that highest correlation between body weight and chest girth. This shows that heart girth might be the best trait to estimate live body weight for goats and other livestock species.

\subsubsection{Prediction of Body Weight of Goats from Different Body Measurements}

Multiple linear regression models for predicting the body weight of goats from linear body measurements are presented in Table 28. Multiple linear regression equations were developed to predict dependent variable (BW) from different independent variables. The accuracy of functions used to predict live weight or growth characteristics from live animal measurements have enormous contribution on the improvement of livestock production and productivity (Tesfaye, 2008). If there is no availability of equipments and materials for measuring body weight, heart girth measurement might be sufficient for prediction of body weight and mathematical equations can be developed based on actual weight-linear body measurements data (Solomon and Kassahun, 2008).

Stepwise regression procedure was carried out to generate models (equations) for prediction of body weight of both male and female goats separately from linear measurements. The best fitted prediction model was selected with smaller the mallow's parameters C (P), mean square error (MSE) and higher

$\mathrm{R}^{2}$ values. From the result of stepwise multiple regression analysis, the most important variable for predicting body weight was heart girth than the other variables in both sexes in does (91\%) and 
bucks (92\%). This is in agreement with the results of Ahmed (2013), Belete (2013), Hulunim (2014) and Alubel (2015) as chest girth was selected first for prediction of live body weight of animals. Thus, prediction of body weight could be based on regression equation $y=-53.23+1.18 x$ for female sample population and $\mathrm{y}=-45.16+1.06 \mathrm{x}$ for male sample goat population where, $\mathrm{y}$ and $\mathrm{x}$ are body weight and heart girth, respectively. Even though the increment of $\mathrm{R}^{2}$ was small in each steps in the model, combination of more than one variables clearly indicated that weight could be estimated more accurately by combination of two or more variable. This may be decrease the values of $\mathrm{C}(\mathrm{P})$, MSE which will ultimately increases the efficiency of the model. However, according to Grum (2010) and Tesfaye (2008), considering more variables under extensive management conditions will be unpractical due to cost and accuracy problems. So, live body weight estimation using chest girth alone would be better under extensive management conditions.

\section{CONClusion}

Phenotypic characterization of this study indicated high variation within and between the studied indigenous goats in most qualitative and quantitative traits. On average in Minjar -Shenkora district goats are higher in body size than other districts goat this may be the environmental and management difference. The existing higher variability within and between indigenous goats would be useful for future genetic improvement through selection and breed conservation.

\section{REFERENCES}

[1] Adane Hirpa and Girma Abebe, 2008. Economic significance of sheep and goats. Pp. 325-340. In: Alemu Yami and R C Merkel (eds.). Sheep and Goat Production Handbook of Ethiopia.ESGPIP (Ethiopian sheep and goat productivity improvement program). Branna Printing Enterprise. Addis Ababa, Ethiopia.

[2] Ahmed Seid, 2013. On-farm phenotypic and production system Characterization of indigenous goats in Horro Guduru Wollega Zone, Western Ethiopia M.sc. thesis Haramaya, university.112p.

[3] Alefe Takele, 2014. Phenotypic characterization of indigenous goat types and their production system in Shabelle Zone, South Eastern Ethiopia M.sc. Thesis Haramaya university. 130p

[4] Alubel Alemu, 2015. On-farm phenotypic characterization and performance evaluation of Abergelle and Central Highland goat breeds as an input for designing community-based breeding program Msc thesis Haramaya university, 2015.147p

[5] Ameha Sebsibe, 2008. Sheep and goat meat characteristics and quality. In: Alemu Yami and R.C. Merkel (Eds). Sheep and goat production handbook for Ethiopia. Ethiopian sheep and goats productivity improvement program (ESGPIP), Addis Ababa Ethiopia. pp 323-328. USAID.

[6] Ayalew, W., Getahun, E., Tibbo, M., Mamo, Y. and Rege, J.E.O., 2004. Current states of knowledge on characterization of farm Animal Genetic Resource in Ethiopia. In: Proceeding of the 11th Annual conference of Ethiopian Society of Animal Production (ESAP). August 28-30, 2004. Addis Ababa, Ethiopia. pp. 1-21

[7] Ayalew W., Rischkowsky B., King J.M. and Bruns E. (2003). Crossbreds did not create more net benefits than indigenous goats in Ethiopian smallholdings. Agric. Sys 76:1137- 1156.

[8] Belay Zeleke, Meseretu Melese, 2017. On farm phenotypic characterization of indigenous goat populations in Gamo Gofa zone south western Ethiopia. Journal of Advanced Studies in Agricultural, Biological and Environmental Sciences (JABE) Vol.4.Issue.3.2017, Arba Minch, University Ethiopia

[9] Belete Assefa. 2013 .On farm phenotypic characterization of indigenous goat types and their production system in bale zone of Oromia region, Ethiopia. MSc Thesis Submitted to the School of Graduate Studies, Through School of Range science and animal science 2013.116p

[10] Belete Shenkute. 2009. Production and marketing systems of small ruminants in Goma district of Jimma Zone, Western Ethiopia. MSc thesis. Hawassa, Ethiopia: Hawassa University.

[11] Bekalu Muluneh, 2014. Phenotypic characterization of indigenous goat types and their production system in West Gojam Zone of Amhara region, Ethiopia. MSc Thesis Haramaya university.109p

[12] CSA, 2012. Federal Democratic Republic of Ethiopia, Agricultural sample survey 2011/2012

[13] (2004 E.C.) Report on crop and livestock product utilization (private peasant holdings, meher

[14] Season) No. 532, Vol.3, Addis Ababa, Ethiopia

[15] CSA, 2016. Federal Democratic Republic of Ethiopia, Agricultural sample survey 2016/2017 (2004 E.C.) Report on livestock and livestock product characteristics (private peasant holdings). No. 585, Volume II, Addis Ababa, Ethiopia

[16] Dereje Tsegaye. 2011. Herd husbandry and breeding practices of goat in different agro-ecologies of Western Hararghe, Ethiopia. MSc thesis. Jimma, Ethiopia: Jimma University. 
[17] ESGPIP (Ethiopia Sheep and Goat Productivity Improvement Program). 2009. Goat breeds of Ethiopia: A guide for identification and utilization. Technical Bulletin 27. Addis Ababa, Ethiopia: ESGPIP.

[18] Ethiopia Sheep and Goat Productivity Improvement Program (ESGPIP), 2008. Sheep and goat hand book.

[19] FAO. 1997. Production Yearbook. Food and Agriculture Organization. Rome, Italy.

[20] FAO, 2007. Global plan of action for animal genetic resources and the inter laken declaration, Rome, Italy

[21] FAO (food and agricultural organization), 2011. Draft guidelines on phenotypic characterization of animal genetic resources. Commission on genetic resources for food and agriculture, thirteenth regular session.

[22] FARM Africa, 1996. Goat types of Ethiopia and Eritrea. Physical description and management systems. Published jointly by FARM-Africa, London, UK, and ILRI (International Livestock Research Institute), Nairobi, Kenya.76 pp.

[23] FAO, 2012. Draft Guidelines on Phenotypic Characterization of Animal Genetic Resources. Commission on Genetic Resources for Food and Agriculture. Thirteenth, Regular session, Rome, 18-22 July 2012.

[24] Feki Misbah, 2013. Community-Based Characterization of Afar Goats Breeds in Aysaita District of Afar Region. An MSc thesis submitted to School of Animal and Range Science, School of Graduate Studies Haramaya University. 129pp.

[25] Getahun, Legesse. 2008. Productive and Economic Performance of Small Ruminant Production in two Production System of the Highlands of Ethiopia. PhD, dissertation.University of Hohenheim, StuttgartHoheinheim, Germany.

[26] Getnet A., Hegde, B.P., Bekele T., Enyew N. and Workneh A. 2005. Phenotypic characterization of goat types in northwestern Ethiopia. Ethiopian Journal of Animal Production 5:13-32.

[27] Getinet M. 2016. Molecular characterization of Ethiopian indigenous goat populations: genetic diversity and structure, demographic dynamics and assessment of the kisspeptin gene polymorphism Degree of Doctor of Philosophy in Applied Genetics Addis Ababa University. 274p.

[28] Grum Gebreyesus, 2010. Community-Based Participatory Characterization of the short Eared Somali Goat Population around Dire Dawa. An MSc thesis submitted to School of Animal and Range Science, School of Graduate Studies Haramaya University. 129pp.

[29] Halima Hassen, Michael Baum, Barbara Rischkowsky and Markos Tibbo., 2012.Phenotypic characterization of Ethiopian indigenous goat populations. African Journal of Biotechnology 11(73), pp13838-13846.

[30] Hulunim Gatew, 2014. On-Farm Phenotypic Characterization and Performance Evaluation of Bati, Borena and Short Eared Somali Goat Populations of Ethiopia. MSc thesis, Submitted to the School of Graduate Studies of Haramaya University, Ethiopia. 140p.

[31] Hussein, H.T. 2015. Phenotypic characterization and breeding practices of Arsi-Bale goat population in selected districts of Arsi and Bale zones, Oromia regional state, Ethiopia. MSc thesis. Bahir Dar University, Bahir Dar, Ethiopia.

[32] ILCA, 1990. (International livestock centre for Africa). Livestock research Manual systemmanual. ILCA, Addis Ababa, Ethiopia. Part I. 287p.

[33] Kassahun Awgichew and Solomon Abegaz. 2008. Breeds of sheep and goats. pp 5-26. In: Alemu Yami and R.C. Merkel (eds.). Sheep and goat production handbook for Ethiopia. Ethiopian sheep and goat productivity improvement program, USAID.

[34] Khan, H., F. Muhammd, R. Ahmed, G. Nawaz, Rahimullah and M. Zibair, 2006.Relationship of body weight with linear body measurements in goats.Journal of Agricultural and Biological Science. Asian Research Publishing Network (ARPN) 1:3.

[35] Mahilet Dawit, 2012. Live characterization of Hararghe highland goat and their production system in eastern Hararghe. M.Sc. thesis presented to School of Graduate Study of Haramaya University.

[36] Markos Tibbo, 2006. Productivity and health of indigenous sheep breeds and crossbreds in the central Ethiopia highlands. PhD dissertation. Department of Animal Breeding and Genetics, Faculty of Veterinary Medicine and Animal Sciences, Swedish University of Agricultural Science(SLU), Uppsala, Sweden.pp74.

[37] Nigatu Alemayehu. 1994. Characterization of indigenous goat types of Eritrea, Northern and Western Ethiopia. M.Sc. Thesis, Alemaya University of Agriculture. Alemaya, Ethiopia. 136p

[38] Rege, J.E.O. and Okeyo, A.M., 2006. Improving our knowledge of tropical indigenous animal genetic resources In: Animal Genetics Training resource, version 3, 2011. Ojange, J.M. Magmfors, B. and Okeyo, M.(Eds). International Livestock Research Institute, Nairobi, Kenya, and Swedish University of Agricultural Sciences, Uppsala, Sweden.

[39] SAS (Statistical Analysis System), 2008. SAS for windows, Release 9.3 SAS interprize, Inc., Cary, NC, USA.

[40] SPSS Version, 20.0 (2013).Software Package for Social Sciences for Window. 
[41] Solomon Abegaz, Girma Abebe and Kassahun Awgichew, 2008. Sheep and Goat Production Systems in Ethiopia, Addis Ababa Ethiopia, 28-29 p

[42] Solomon Abegaz, 2013. Design of Community Based Breeding programs for two indigenous goat breeds of Ethiopia.PhD desertation. BOKU-University of Natural Resources and Life sciences, Department of Sustainable Agricultural Systems, Division of Livestock Sciences, Vienna, Austria. 100pp.

[43] Tegegne Fantahun Chernet. 2012. On-farm phenotypic characterization of goat genetic resources in Bench Maji zone,southwestern Ethiopia. MSc thesis. Bahir Dar, Ethiopia: Bahir Dar University.

[44] Tesfaye Alemu. 2004. Genetic characterization of indigenous goat populations of Ethiopia using microsatellite DNA markers, PHD thesis, National Dairy Institute, Haryana, India. 188p.

[45] Tesfaye Kebede, Tesfaye Lemma, Hunduma Dinka, Mieso Guru, and Amsalu Sisay, 2008. Growth performance and carcass characteristics of Arsi-Bale goats castrated at different ages. Journalofcell and Animal Biology 2 (11) pp187-194

[46] Tesfaye Kebede, Aynalem Haile and Hailu Dadi. 2012a. Smallholder goat breeding and flock management practices inthe central rift valley of Ethiopia. Tropical Animal Health Production 44(5):999-1006.

[47] Tesfaye Kebede, Aynalem Haile, Hailu Dadi and Tesfaye Alemu. 2012b. Genetic and phenotypic parameter estimates for reproduction traits in indigenous Arsi-Bale goats. Tropical Animal Health Production 44:1007-1015

[48] Tesfaye Tsegaye, 2009. Characterization of Goat Production Systems and On- Farm Evaluation of the Growth Performance of Grazing Goats Supplemented With Different Protein Sources in Metema, Amhara Region, Ethiopia. MSc Thesis, Submitted to the School of Graduate Studies of Haramaya University, Ethiopia. 108P.

[49] Tsedeke K. 2007. Production and marketing systems of sheep and goats in Alaba, southern Ethiopia. MSc thesis. Awassa, Ethiopia: Hawassa University.

[50] Tsigabu Gebreslassie, 2015. Phenotypic characterization of indigenous goat types and their production system in Gambella region Ethiopia Msc. Thesis Haramaya university.93p

[51] Workneh Ayalew, 1992. Preliminary Survey of Indigenous Goat Types and Goat Husbandary Practices in Southern Ethiopia. An MSc Thesies Presented to School of Graduate Studies of Alemaya University of Agriculture, Alemyaya, and Ethiopia.pp170.

[52] Yakubu A (2010a). Path coefficient and path analysis of body weight and biometric traits in Yankasa lambs. Slovak J. Anim. Sci. 43:17-25.

[53] Yaekob Lorato, Kirman Manzoor Ahmed and Birhanu Belay, 2015. Morphological characterization of indigenous Woyto-Guji goat type in Loma district, Southern Ethiopia. Afr. J. Agric. Res. Vol. 10(20), pp. $2141-2151$

[54] Zewdu W., Workneh A., Sölkner J (2006). Breeding scheme based on analysis of community breeding objectives for cattle in north-western Ethiopia. Ethiopian Journal of Animal Production 6(2): 53-66.

Citation: Hailu Tilahun, et.al, "Phenotypic Characterization of Indigenous Goats in North Shewa Zone, Amhara Region, Ethiopia” International Journal of Research Studies in Agricultural Sciences (IJRSAS), 2019; 5(7), pp. 44-55, http://dx.doi.org/10.20431/2454-6224.0507005

Copyright: (C) 2019 Authors. This is an open-access article distributed under the terms of the Creative Commons Attribution License, which permits unrestricted use, distribution, and reproduction in any medium, provided the original author and source are credited. 